\title{
Comparative Study of Amsel Criteria Vs Nugent Criteria- Scoring System In Vaginal Discharge in Gmkmch, Salem.
}

\author{
Dr. M.Banupriya Dgo, M.S Og., Dr.N.Geetha M. D Og
}

\begin{abstract}
Introduction: Bacterial Vaginosis is the commonest cause of abnormal vaginal discharge in women of reproductive age group .It is a polymicrobial syndrome by replacement of lactic acid producing species to mycoplasma and gram negative rods. Bacterial Vaginosis has been diagnosed using Amsel criteria and Nugent scoring system. This study was undertaken to compare the diagnostic ability of Amsel Criteria with that of Nugent Scoring among patients attended in Gynaec OPD.

Methodology:This study was conducted at Govt Mohan Kumaramangalam Medical College ,Salem .In this study prevalence of BV Specificity and Sensitivity, Positive Predictive Value, Negative Predictive Value of Amsel Criteria was noted and each components of Amsel Criteria was compared to Nugent Scoring system.

Result: In this study prevalence of Bacterial Vaginosis according to Amsel Criteria was 31.80\% and Nugent scoring system was 20.80\%. Sensitivity and Specificity of Amsel Criteria were 100\%and 91.20\%, Positive Predictive Value was $84.12 \%$ and Negative Predictive Value was 100\%.The presence of clue cells co-related best with a positive diagnosis by Nugent Score.

Conclusion: Our study supports the Amsel Criteria for diagnosis of Bacterial Vaginosis by using three out of four criteria, for screening of BV at our patient's clinic.
\end{abstract}

Keywords: Bacterial Vaginosis, Amsel Criteria, Nugent Scoring System

\section{Introduction}

A healthy vagina normally contains Lactobacilli species, L.crispatus, L. gasseri, L.jensenii, and L.iners. The microorganisms involved in BV are Gardnerella Vaginalis, Mycoplasma Hominis, Ureaplasma Urealyticum and Peptostreptococcus and Mobiluncus, as well as anaerobic gram negative rod like Prevotella and Bacteroides.

BV can be associated with sexual activity. Pregnant women and women with sexually transmitted infections are at risk for getting this infection .BV may affect women after menopause.

\section{Material And Methology}

Source of collection: Women attended Gynaec O.P. in the department of Obstetrics and Gynaecology, Government Mohan Kumaramangalam Medical College, Salem.

Study Design: A prospective comparative study was conducted over a period of 10 months involving 500 women in reproductive age group

Sample Size: 500 cases

Ethics: The study was conducted in accordance with the ethical rules of Government Mohan Kumaramangalam Medical College, Salem. Informed written consent to participate in the study was obtained from all participants.

\section{Methodology}

A non -lubricated speculum was passed in to the vagina and noted the characteristics of the discharge with respect to amount, odor, and type of discharge. With the help of sterile cotton tipped swabs from the posterior vaginal fornix four samples of vaginal discharge was collected.

1. The first swab was placed on the litmus paper which to determine the vaginal $\mathrm{PH}$.

2. Two drops of $10 \% \mathrm{KOH}$ solution was added to the second swab, release of fishy amine odor signified a positive whiff test.

3. The third swab was mixed with 2 drops of normal saline on a slide and covered with a cover slip and examined under high power microscopy to look for clue cells.

4. The fourth swab was rolled along the glass sides and smear made, air dried and sent to laboratory. Gram staining was done for Nugent scoring. 


\section{Results And Analysis}

A total of 500 women in the reproductive age group was involved in the study. We consider intermediate scoring in Nugent Scoring as BV negative .Both symptomatic [vaginal discharge ] and asymptomatic women [without discharge ] was involved.

\section{Statistical Analysis}

Data analysis was performed by using descriminant function. Descriptive statistics, chi-square test were used to determine the level of significant differences as applicable. Using Nugent Scoring as the gold standard, we calculated the Sensitivity, Specificity, Positive Predictive Value Negative Predictive Value, of each criterion was individually determined.

\begin{tabular}{|c|c|c|c|c|}
\hline \multicolumn{2}{|l|}{ Amsel Criteria } & \multicolumn{2}{|c|}{ Predicted Group Membership } & \multirow{2}{*}{ Total } \\
\hline \multirow{3}{*}{ Count } & Original & BV Positive & BV Negative & \\
\cline { 2 - 5 } & BV Positive & 104 & 55 & 159 \\
\cline { 2 - 5 } & BV Negative & 0 & 341 & 341 \\
\hline \multirow{3}{*}{$\%$} & BV Positive & 65.41 & 34.59 & 100 \\
\cline { 2 - 5 } & & & & 100 \\
\hline
\end{tabular}

$\mathbf{8 9 . 0} \%$ of original grouped cases correctly classified

\begin{tabular}{|c|c|c|c|c|}
\hline \multicolumn{2}{|c|}{ Nugent Score } & \multicolumn{2}{|c|}{ Predicted Group Membership } & \multirow[t]{2}{*}{ Total } \\
\hline & Original & BV Positive & BV Negative & \\
\hline \multirow{2}{*}{ Count } & BV Positive & 104 & 0 & 104 \\
\hline & BV Negative & 55 & 341 & 396 \\
\hline \multirow{2}{*}{$\%$} & BV Positive & 100 & 0 & 100 \\
\hline & BV Negative & 13.89 & 86.11 & 100 \\
\hline
\end{tabular}

Homogenous Discharge

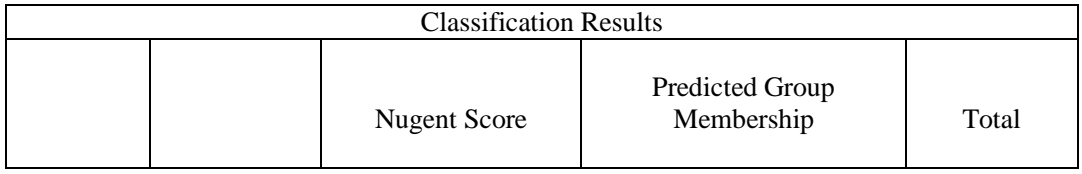




\begin{tabular}{|c|c|c|c|c|c|}
\hline Original & Count & $\begin{array}{c}\text { BV } \\
\text { Positive }\end{array}$ & $\begin{array}{c}\text { BV } \\
\text { Negative }\end{array}$ & \\
\hline & $\%$ & BV Positive & 0 & 104 & 104 \\
\hline & BV Negative & 0 & 396 & 396 \\
\hline & BV Positive & 0 & 100 & 100 \\
\hline & $\begin{array}{c}79.2 \% \text { Of } \\
\text { original } \\
\text { grouped } \\
\text { cases } \\
\text { correctly } \\
\text { classified }\end{array}$ & BV Negative & 0 & 100 & 100 \\
\hline
\end{tabular}

Homogenous Discharge compared to Nugent Score Sensitivity was

$0 \%$ and Specificity was $100 \%$

Positive Predictive Value was $0 \%$

Negative Predictive Value was $79.2 \%$

$\mathrm{PH}$

\begin{tabular}{|c|c|c|c|c|c|}
\hline \multicolumn{6}{|c|}{ Classification Results } \\
\hline \multirow[b]{2}{*}{ Original } & \multirow[b]{2}{*}{ Count } & \multirow[t]{2}{*}{ Nugent Score } & \multicolumn{2}{|c|}{$\begin{array}{l}\text { Predicted Group } \\
\text { Membership }\end{array}$} & \multirow[t]{2}{*}{ Total } \\
\hline & & & $\begin{array}{c}\text { BV } \\
\text { Positive }\end{array}$ & BV Negative & \\
\hline & & BV Positive & 0 & 104 & 104 \\
\hline & $\%$ & BV Negative & 0 & 396 & 396 \\
\hline & & BV Positive & 0 & 100 & 100 \\
\hline & & BV Negative & 0 & 100 & 100 \\
\hline & $\begin{array}{c}79.2 \% \text { Of } \\
\text { original } \\
\text { grouped cases } \\
\text { correctly } \\
\text { classified }\end{array}$ & & & & \\
\hline
\end{tabular}

PH of Amsel Criteria compared to Nugent Score's Sensitivity was

$0 \%$ and Specificity was $100 \%$.

Positive Predictive Value was $0 \%$

WHIFF TEST

\begin{tabular}{|c|c|c|c|c|c|}
\hline \multicolumn{6}{|c|}{ Classification Results } \\
\hline \multirow{2}{*}{ Original } & \multirow[b]{2}{*}{ Count } & \multirow[t]{2}{*}{ Nugent Score } & \multicolumn{2}{|c|}{$\begin{array}{l}\text { Predicted Group } \\
\text { Membership }\end{array}$} & \multirow[t]{2}{*}{ Total } \\
\hline & & & $\begin{array}{c}\text { BV } \\
\text { Positive }\end{array}$ & $\begin{array}{c}\text { BV } \\
\text { Negative }\end{array}$ & \\
\hline & & BV Positive & 104 & 0 & 104 \\
\hline & $\%$ & BV Negative & 86 & 310 & 396 \\
\hline & & BV Positive & 100 & 0 & 100 \\
\hline & & BV Negative & 21.72 & 78.28 & 100 \\
\hline & $\begin{array}{c}89.0 \% \text { Of } \\
\text { original } \\
\text { grouped cases } \\
\text { correctly } \\
\text { classified }\end{array}$ & & & & \\
\hline
\end{tabular}

Negative Predictive Value was $79.2 \%$

Whiff Test of Amsel Criteria compared to Nugent Score Sensitivity

Was $100 \%$ and Specificity was $78.28 \%$

Positive Predictive Value was $54.74 \%$

Negative Predictive Value was $100 \%$ 


\begin{tabular}{|c|c|c|c|c|c|}
\hline \multicolumn{6}{|c|}{ Presence of Clue Cells } \\
\hline \multicolumn{6}{|c|}{ Classification Results } \\
\hline & & Nugent Score & $\begin{array}{r}\text { Pred } \\
\mathrm{M}\end{array}$ & $\begin{array}{l}\text { ted Group } \\
\text { nbership }\end{array}$ & Total \\
\hline \multirow[t]{6}{*}{ Original } & Count & & $\begin{array}{c}\text { BV } \\
\text { Positive }\end{array}$ & BV Negative & \\
\hline & & BV Positive & 104 & 0 & 104 \\
\hline & $\%$ & BV Negative & 10 & 386 & 396 \\
\hline & & BV Positive & 100 & 0 & 100 \\
\hline & & BV Negative & 2.53 & 97.43 & 100 \\
\hline & $\begin{array}{c}89.0 \% \text { Of } \\
\text { original } \\
\text { grouped } \\
\text { cases } \\
\text { correctly } \\
\text { classified }\end{array}$ & & & & \\
\hline
\end{tabular}

Clue cells of Amsel Criteria compared to Nugent Score Sensitivity

Was $100 \%$ and Specificity was $97.47 \%$.

Positive Predictive Value was $91.23 \%$ and

Negative Predictive Value was $100 \%$

Overall Representation of Amsel Criteria compared to nugent score

\begin{tabular}{|c|c|c|c|c|c|}
\hline \multirow{2}{*}{ Original } & Count & Nugent Score & \multicolumn{2}{c|}{ Predicted Group Membership } & Total \\
\hline & & & $\begin{array}{c}\text { BV } \\
\text { Positive }\end{array}$ & BV Negative & \\
\hline & & & & \\
\hline & & BV Positive & 104 & 0 & 104 \\
\hline & & BV Negative & 10 & 386 & 396 \\
\hline & $\begin{array}{c}\text { BV Positive } \\
\text { grouped cases } \\
\text { correctly } \\
\text { classified }\end{array}$ & BV Negative & 2.53 & 97.43 & 100 \\
\hline
\end{tabular}

Amsel Criteria overall compared to Nugent Score Sensitivity was

$100 \%$ and Specificity was $97.47 \%$.

Positive Predictive Value was $91.23 \%$

Negative Predictive Value was $100 \%$

\section{Results}

A total of 500 women were enrolled in the study.

According to Nugent Score BV POSITIVE was 104 WOMEN, PERCENT 20.8

BV NEGATIVE was 160 WOMEN, PERCENT 32

BV INTERMEDIATE was 236 WOMEN, PERCENT 47.2

In our study we consider intermediate flora as BV NEGATIVE , as per Nugent Score BV POSITIVE was 104 PERCENT 20.8 .BV NEGATIVE was 396,PERCENT 79.2.

Over all Amsel Criteria sensitivity was $100 \%$

Amsel Criteria Specificity was $91.20 \%$ and Positive Predictive Value $84.12 \%$ and Negative Predictive Value $100 \%$.Each of the individual components of the Amsel Criteria was compared to the Nugent Score.

The presence of clue cells correlated best with a positive diagnosis by Nugent Score.

\section{Discussion}

The developing country prevalence of Bacterial Vaginosis is 20 to 47 percent in non pregnant women. The prevalence of $\mathrm{BV}$ in pregnant women is 31 percent .Bhalla et al.reported a prevalence of $\mathrm{BV}$ in sexually active non pregnant women is 32 percent.

In our study prevalence of BV according to Amsel Criteria 31.80\% and Nugent Criteria 20.80\%.Proper diagnosis of $\mathrm{BV}$ is challenging. Because of scientific considerations, choosing a method for laboratory diagnosis requires consideration of complexity, cost, and frequency of un interpretable specimens. 
In developing country the Amsel and Nugent methods remain the most practical, viable and economical options for diagnosing Bacterial Vaginosis. The predictive of BV determined using Amsel Criteria as a diagnostic tool was found to be $31.80 \%$ and Nugent Criteria as $20.80 \%$. This study found sensitivity of Amsel Criteria was $100 \%$ and specificity $91.2 \%$. Our study showed Amsel Criteria were taken as the definition of Bacterial Vaginosis. Since the pathogenic organisms involved in Nugent method are themselves normal residents of the vaginal flora, which might be an acceptable level to some patients, could cause extreme discomfort to others .

In this study each of the components of the Amsel Criteria was correlated with the Nugent Score. Presence of clue cells had the best correlation with the Nugent Score, as all patients found positive by Nugent Criteria had demonstrable amounts of clue cells.

Though the presence of clue cells had the best correlation and was the single most sensitive criterion, involves the use of a microscope. The among the four Criteria of Amsel detection of clue cells is the most complicated and requires the use of expensive resources ,similar to Nugent Scoring System.

Thus inspite of being a sensitive criterion, detection of clue cells may not be the best indicator of Bacterial Vaginosis on a practical basis in clinical settings, as suggested by hilliers et al. Thin homogenous vaginal discharge is not accurately interpreted.

The whiff test is dependent on the power of smell, which vary from person to person. A positive whiff test is highly suggestive of Bacterial Vaginosis, a negative test always be treated with caution. The PH seemed to be the best indicator of Bacterial Vaginosis it is one which could be objectively measured at the bed side. In this study we consider intermediate score of Nugent as BV negative.

This study suggests Amsel Criteria is a convenient and inexpensive way to diagnosis the Bacterial Vaginosis. This study also suggests each components of the Amsel Criteria was compare to Nugent Scoring System, PH of the discharge, nature of the discharge has been eliminated. The whiff test and clue cells best corelated with Nugent Scoring System. For diagnosis of Bacterial Vaginosis detection of clue cells requires much infrastructure like Nugent Scoring System.

\section{Conclusion}

Our study supports the Clinical Criteria-Amsel Criteria for diagnosis of Bacterial Vaginosis by using three out of four Criteria, for screening of women for Bacterial Vaginosis at out patient's clinic.

The nature of discharge and PH and amine odor tests are cost effective in developing country and low resource settings. Early diagnosis of this infection prevents the further complications by commencing appropriate treatment.

\section{Acknowledgement}

I gratefully acknowledge and sincerely thank our beloved Dean Dr.P.kanagaraj ,MD., Government Mohan Kumaramangalam Medical College and Hospital ,for this whole hearted co-operation and support for the completion of this study .

My sincere thanks to Dr.N.Geetha M.D., O.G., Associate professor, department of obstetrics and gynecology Government Mohan Kumaramangalam Medical College and Hospital, whose provide constant encouragement and guidance in the preparation of this study.

My sincere thanks to Dr.Elangovan M.D., Professor, department of microbiology, Government Mohan Kumaramangalam Medical College and Hospital, who provide guidance in the preparation of this study.

\section{Reference}

[1]. Sobel JD. Bacterial Vaginosis. Annu Rev Med 2000; 51:349-56.

[2]. Rao PS, Devi S, Shriyan A, Rajaram M, Jagdishchandra K. Diagnosis of bacterial Vaginosis in a rural set up: comparison of clinical algorithm, smear scoring and culture by semi quantitative technique. Indian J Med Microbiol2004; 22(1):47-50.

[3]. Dadhwal V, Hariprasad R, Mittal S, Kapil A. Prevalence of bacterial Vaginosis in pregnant women and predictive value of clinical diagnosis. Arch GynecolObstet 2009, [Epub ahead of print]

[4]. Honest H, Bachmann LM, Knox EM, Gupta JK, Kleijnen J, Khan KS. The accuracy of various tests for bacterial Vaginosis in predicting preterm birth: a systematic review. BJOG. 2004; 111(5):409-22.

[5]. Mohanty S, Sood S, Kapil A, Mittal S. Interobserver variation in the interpretation of Nugent scoring method for diagnosis of bacterial Vaginosis. Indian J Med Res 2010; 131:88-91.

[6]. Demba E, Morison L, MaartemSchim VDL, et al. Bacterial Vaginosis, vaginal flora patterns and vaginal hygiene practices in patients presenting with vaginal discharge syndrome in the Gambia, West Africa. BMC Infect Dis2005; 5:12-24

[7]. Ferris DG, Francis SL, Dickman ED, Miler-Miles K, Waller JL, McClendon N. Variability of vaginal pH determination by patients and clinicians' Am Board Fam Med.2006; 19:368-73.

[8]. Cohrssen A, Anderson M, Merrill A, McKee D.Reliability of the whiff test in clinical practice. J Am Board FamPract. 2005; 18:561-2.

[9]. Silonie S. Clue cell. Indian J DermatolVenerolLeprol. 2006; 72: 392 - 3.

[10]. Collee JG, Miles RS. Tests for identification of bacteria. In Mackie and McCartney Practical Medical Microbiology, 13th ed.Collee JG, Fraser AG, Duguid JP, Marmion BP (eds) Edinburg: Churchill Livingstone 1989; pp141-160. 